\title{
Implication of anaerobic and aerobic decomposition of Eichhornia azurea (Sw.) Kunth. on the carbon cycling in a subtropical reservoir
}

\author{
Bianchini Junior, I. ${ }^{\mathrm{a}, \mathrm{b} *}$, Cunha-Santino, MB. ${ }^{\mathrm{a}, \mathrm{b}}$, Ribeiro, JU. ${ }^{\mathrm{a}}$ and Penteado DGB. ${ }^{\mathrm{a}}$ \\ ${ }^{a}$ Departamento de Hidrobiologia, Universidade Federal de São Carlos - UFSCar, \\ Rod. Washington Luiz, km 235, CP 676, CEP 13565-905, São Carlos, SP, Brazil \\ bPrograma de Pós-graduação em Ecologia e Recursos Naturais, Universidade Federal de São Carlos - UFSCar, \\ Rod. Washington Luiz, km 235, CP 676, CEP 13565-905, São Carlos, SP, Brazil \\ *e-mail: irineu@ufscar.br
}

Received: August 27, 2012 - Accepted: December 19, 2012 - Distributed: February 28, 2014

(With 2 figures)

\begin{abstract}
This study aimed at describing kinetic aspects of aerobic and anaerobic mineralization of Eicchornia azurea. The samples of aquatic macrophyte and water were collected in the Monjolinho Reservoir $\left(22^{\circ} 00^{\prime} \mathrm{S}\right.$ and $\left.47^{\circ} 54^{\prime} \mathrm{W}\right)$. To determine the leachate potential, dried plant fragments were added to reservoir water, with sampling lasting for 4 months, where the particulate and dissolved organic carbon concentrations were measured. The kinetics of mass loss was obtained with 10 mineralization chambers for both aerobic and anaerobic conditions, with the plant fragments and reservoir water. Two additional chambers were used to monitor the volume of gases produced from anaerobic mineralization, with bioassays to determine oxygen uptake. The results were fitted to a first-order kinetic model, from which $27.21 \%$ of detritus corresponded to labile/soluble fractions and $72.62 \%$ to the refractory fractions. The decay rates for the global mass losses of the labile/soluble components were 2.07 day $^{-1}$. DOC mineralization was not verified for either condition. Under aerobic condition, the mass loss constant rate $\left(0.0029\right.$ day $\left.^{-1}\right)$ for the refractory fractions was 2.4 the value for the anaerobic one. Under anaerobic condition, the gases formation occurred in three phases. Based on these results, in the Monjolinho Reservoir, the decomposition of E. azurea that undergo within the water column and in upper layers of sediment is a faster process, favoring the mineralization. In contrast, in the lower layers of sediment the diagenetic processes (i.e. humus production and accumulation of organic matter) are favored.
\end{abstract}

Keywords: decay, oxygen consumption, gases formation, aquatic macrophyte, Monjolinho Reservoir.

\section{Implicações da decomposição aeróbia e anaeróbia de Eichhornia azurea (Sw.) Kunth. na ciclagem de carbono em um reservatório subtropical}

\begin{abstract}
Resumo
Nesse estudo descreveram-se aspectos cinéticos da decomposição aeróbia e anaeróbia de Eichhornia azurea. As amostras da macrófita aquática e de água foram coletadas no reservatório do Monjolinho (22 $00^{\prime} \mathrm{S}$ e $47^{\circ} 54^{\prime}$ O). Para a determinação do potencial de lixiviação, adicionaram-se fragmentos de planta (previamente secos) em água do reservatório. Nos experimentos de decomposição, as amostragens foram realizadas durante 4 meses e quantificaram-se as frações particuladas e dissolvidas de carbono. Para descrever as cinéticas de perda de massa, para cada condição (aeróbia e anaeróbia) foram preparadas 10 incubações contento fragmentos de plantas e água do reservatório. A cada dia de amostragem as frações particuladas e dissolvidas de carbono orgânico foram quantificadas. Foram também preparadas 2 câmaras para registrar a formação de gases da degradação anaeróbia e o consumo de oxigênio na degradação aeróbia. Os resultados foram ajustados a um modelo cinético de $1^{\text {a }}$ ordem. Verificou-se que $27,21 \%$ dos detritos corresponderam à fração lábil/solúvel e $72,62 \%$ à refratária. O coeficiente global de perda de massa das frações lábeis/solúveis foi 2,07 dia $^{-1}$. Nas duas condições não houve mineralização da matéria orgânica dissolvida. Na condição aeróbia, o coeficiente de perda de massa das frações refratárias $\left(0,0029 \mathrm{dia}^{-1}\right)$ foi 2,4 vezes maior que o da anaeróbia. Para a condição anaeróbia observou-se que a formação de gases constituiu-se de três fases. Diante destes resultados, no reservatório do Monjolinho, os processos degradativos dos detritos de $E$. azurea que ocorrem tanto na coluna d'água quanto na superfície do sedimento são mais rápidos, favorecendo assim, a mineralizaçao; por outro lado, no sedimento os processos diagenéticos (i.e. humificação e o acúmulo de matéria orgânica) são favorecidos.
\end{abstract}

Palavras-chave: degradação, consumo de oxigênio, formação de gases, macrófita aquática, reservatório do Monjolinho. 


\section{Introduction}

Carbon fixation in the littoral zone of lentic ecosystems is usually distinct from limnetic zones, since the lakeshore is often colonized by several species of aquatic macrophytes that contribute with massive amounts of particulate and dissolved organic carbon during decomposition. A survey in the literature pointed to considerable primary productivity of macrophytes in different types of wetlands (freshwater: bog, marsh), deep-water and riverine and estuarine waters (fresh tidal, brackish, mangrove) (Batzer and Sharitz, 2006). The primary net productivity of emergent aquatic macrophyte in freshwater systems and mangroves is often comparable to that from a rain forest; for instance, a value ranging from 19 to $37.5 \mathrm{Mg} \mathrm{C} \mathrm{ha}^{-1}$ year $^{-1}$ was reported for tropical freshwater emergent macrophytes (Wetzel, 2001), while for a tropical rain forest the primary net productivity varied from 1.7 to $21.7 \mathrm{Mg} \mathrm{C} \mathrm{ha}^{-1}$ year $^{-1}$ (Clark et al., 2001).

Primary productivity of aquatic macrophyte is driven by abiotic and biotic processes such as temperature, solar radiation, nutrients, water velocity (Biudes and Camargo, 2008), ratio of herbivory (Lodge, 1991) and flooding pulse (Silva et al., 2009). Thus, these organisms are not only important to a high primary productivity or for their interactions with wildlife; they also play a major role in the cycling of various elements. Macrophytes may be the main source of autochthonous detritus of littoral zones in lentic environments (Wurzbacher et al., 2010). With plant senescence, the loss of cellular integrity promotes rapid dissolution of large amounts of components (Gulis and Suberkropp, 2003). The conversion of the detritus of aquatic plants into dissolved organic matter (DOM) is crucial for maintaining biogeochemical cycles in aquatic environments (Benner et al., 1986). The accumulation of detritus is usually regulated by the amount of material entering the system and its decay rate (Currie et al., 2003).

Decomposition of organic matter is a biological process that undergo in aquatic environments naturally (Canhoto and Graça, 1996). The velocity of degradation is determined by intrinsic and extrinsic factors as: type of decomposing organisms and the enzymatic capacity of the microbial community, the abiotic environment (e.g. temperature, availability of dissolved oxygen, $\mathrm{pH}$, reduction-oxidation potential) and also the quality of the organic matter, i.e. concentration and chemical characteristics of the resource (e.g. molecular weight, origin and composition).

During aquatic decomposition process, different products are released depending on biochemical route that organic matter is processed. In aerobic decomposition the main products are: carbon dioxide, water and humic compounds. In anaerobic process, the mains products are carbon dioxide, methane, humic substances, mercaptans, molecular hydrogen, and sulfide hydrogen (Sanderman and Amundson, 2005).

Given the importance of degradation of the aquatic macrophytes for the maintenance of energy flux and detritus food-webs of a lentic aquatic ecosystems, this study discusses the carbon kinetics through the aerobic and anaerobic decomposition of an aquatic macrophyte (Eichhornia azurea) and the implication of decay on carbon metabolism of reservoir.

\section{Materials and Methods}

\subsection{Area description}

The Monjolinho Reservoir ( $22^{\circ} 00^{\prime} \mathrm{S}$ and $\left.47^{\circ} 54^{\prime} \mathrm{W}\right)$ is a subtropical, shallow artificial system (São Carlos, $\mathrm{SP}$, Brazil). It is a small reservoir, with $3.0 \mathrm{~m}$ maximum depth, floodplain basin of $47.157 \mathrm{~m}^{2}$ and a volume of $73.251 \mathrm{~m}^{3}$. Depending on the season, the hydraulic retention time ranges from ca. 2 days (rainy season) to 23 days (dry season) (Nogueira and Matsumura-Tundisi, 1994). This physical feature is responsible for unstable hydraulic characteristics, with entire mixture of water column and also sediment resuspension affecting plankton community (Regali-Seleghim, 1992; Sotero-Santos et al., 2010). The Monjolinho River is a main tributary of this reservoir; its headwaters are located at ca. $7.5 \mathrm{~km}$ upward the reservoir, in an area without riparian vegetation and silted up (Fusari, 2006). The age of its impoundment is unknown, but with the reconstruction of the dam in 1970, the reservoir area was extended to 4.69 ha. According to a limnological survey (period: 2007 and 2008), the trophic state of Monjolinho Reservoir is classified as eutrophic-hypereutrophic. In this environment the main factors determining water quality are the anthropogenic pressures (i.e. inputs of nutrients and organic matter) and hydrological cycle (Marinelli et al., 2000; Santos et al., 2011).

\subsection{Species description}

Eichhornia azurea (Sw.) Kunth belongs to Pontederiaceae family. The leaves are petiolate with wide stipule surrounding the stem, sagittal or oval and inflated petiole (Joly, 1977). The inflorescence is purple-blue measuring ca. 4 to $6 \mathrm{~cm}$ (Correll and Correll, 1972). It is a perennial fixed floating aquatic macrophyte, characterized by zigzag growth and being rhizomatous, reaching from 1 to $8 \mathrm{~m}$ in length. Young plants are submerged with linear leaves (Pott and Pott, 2000). They present floating or trailing stems, often stoloniferous, and the roots are adventitious (Notare, 1992).

\subsection{Collection and preparation of material}

Samples of water and individuals of E. azurea were collected in the littoral zone of Monjolinho Reservoir. In order to remove the periphyton, sediment particles and coarse materials adhered to plant detritus, the plants samples were washed with tap and also distilled water, dried at low temperature $\left(40^{\circ} \mathrm{C}\right)$ until constant mass after, the detritus were homogenized. The reservoir water samples were collected with 5-liter Van Dorn bottles (at $1.5 \mathrm{~m}$ of depth).

\subsection{Determination of leaching potential}

In laboratory six chambers were prepared to establish the leaching potential of soluble fractions of $E$. azurea detritus. In this procedure, $4.0 \mathrm{~g}$ of plant fragments (dry mass - DM) were added to $400 \mathrm{ml}$ of pre-filtered reservoir water. 
The vials were kept in the dark at $23.6 \pm 0.8^{\circ} \mathrm{C}(\mathrm{n}=6)$. For 6 days, the contents of a chamber was fractionated daily by filtration ( $\phi=1.2 \mathrm{~mm}$; Millipore) followed by centrifugation (1 h; $978 \mathrm{~g})$. The concentrations of dissolved organic carbon (DOC) were determined by combustion and non-dispersive infrared detection in a TOC Analyzer (Shimadzu 5000A). The remaining detritus were dried $\left(40{ }^{\circ} \mathrm{C}\right)$ until constant mass. The particulate organic matter (POM) was determined gravimetrically and converted to a carbon-based metric (particulate organic carbon - POC). For the conversions the detritus carbon content was taken as $44.4 \%$, obtained from determination $(n=2)$ in fragments of intact E. azurea in a CHN Analyser (Carlo Erba EA1110). The POC and DOC variations were used to determine: (i) the daily rates of POC mass loss; (ii) the yields of labile, soluble $\left(\mathrm{POC}_{\mathrm{LS}}\right)$ and refractory $\left(\mathrm{POC}_{\mathrm{R}}\right)$ contents of detritus and (iii) the global coefficient of mass loss of $\mathrm{POC}_{\mathrm{LS}}$ (leaching + oxidation of labile compounds). For estimating these parameters, a non-linear regression method was used with the iterative algorithm of LevenbergMarquardt (Press et al., 2007).

\subsection{Decomposition experiments}

Decomposition chambers $(n=20)$ were prepared and incubated under aerobic conditions (with continuous bubbling with compressed filtered air) and under anaerobic conditions. In each chamber, $4.0 \mathrm{~g}$ (DM) of E. azurea fragments were added to $400 \mathrm{ml}$ filtered water sample $(\phi=1.2 \mathrm{~mm}$; Millipore). The experiments were kept in the dark at $24.0 \pm 1.25^{\circ} \mathrm{C}(\mathrm{n}=114)$.

Based on the kinetics of oxygen consumption for this resource described by Bitar and Bianchini Junior (2002) and on the maximum amount of dissolved oxygen (DO) available in each chamber $\left([\mathrm{DO}]_{\text {sat }}\right.$ for $24.0^{\circ} \mathrm{C} \approx 8.42 \mathrm{mg}$ $1^{-1} \times 0.41=3.37 \mathrm{mg}$ ), we observed the mixtures to become anaerobic in a maximum of $1.0 \mathrm{~h}$ after the introduction of plant fragments in the water. Once prepared, the chambers used in the anaerobic processes were closed, being opened only on the sampling days $(1,3,5,10,15$, $20,30,60,91,126$ days). On these days the particulate fraction (POM) were fractionated from dissolved fraction (DOM) by pre-filtration and centrifugation (1 h; $978 \mathrm{~g}$ ). The samples were dried at $50{ }^{\circ} \mathrm{C}$ until constant mass and the final mass was determined gravimetrically. Aliquots of DOM $(200 \mathrm{ml})$ were dehydrated in a heated plate at low temperature (ca. $50{ }^{\circ} \mathrm{C}$ ) and the final mass was determined gravimetrically (Wetzel and Likens, 1991). The mass of POM and DOM was converted into a carbon basis, where the carbon content of POM was measured with an elemental analyzer (Carlo Erba EA1110 CHN Analyzer). The dissolved fractions (DOM) were converted into carbon-based according to the ratio obtained by Tartaglia (2001) for the leachate of aquatic macrophytes. The organic carbon mineralization (MC) was estimated from the differences between the initial carbon content of plant fragments and its content on the remaining detritus (particulate and dissolved forms).

\subsection{Kinetic hypothesis for Eichhornia azurea decomposition}

Assuming a first-order kinetics for the reactions involved in the mineralization of E. azurea (Bianchini Junior and Cunha-Santino, 2011) we propose Equations 1 to 4 to represent the kinetics of this degradation process (two-compartment model).

$$
\begin{aligned}
& \mathrm{IN}_{1}=\frac{\mathrm{k}_{1}}{\mathrm{k}_{\mathrm{T}}} \mathrm{POC}_{\mathrm{LS}}\left(1-\mathrm{e}^{-\mathrm{k}_{\mathrm{T}} \mathrm{t}}\right) \\
& \mathrm{IN}_{2}=\frac{\mathrm{k}_{2}}{\mathrm{k}_{\mathrm{T}}} \operatorname{POC}_{\mathrm{LS}}\left(1+\frac{\mathrm{k}_{3}}{\mathrm{k}_{\mathrm{T}}-\mathrm{k}_{3}} \mathrm{e}^{-\mathrm{k}_{\mathrm{T}} \mathrm{t}}+\frac{\mathrm{k}_{\mathrm{T}}}{\mathrm{k}_{3}-\mathrm{k}_{\mathrm{T}}} \mathrm{e}^{-\mathrm{k}_{3} \mathrm{t}}\right) \\
& \mathrm{IN}_{3}=\operatorname{POC}_{\mathrm{R}}\left(1-\mathrm{e}^{-\mathrm{k}_{4} \mathrm{t}}\right)
\end{aligned}
$$

$\mathrm{MC}=\sum_{\mathrm{i}=1}^{3} \mathrm{IN}_{\mathrm{i}}$

where: $\mathrm{POC}_{\mathrm{LS}}=$ labile and soluble particulate organic carbon $(\%) ; \mathrm{POC}_{\mathrm{R}}=$ refractory particulate organic carbon $(\%) ; \mathrm{IN}_{1}=$ labile organic carbon mineralized $(\%) ; \mathrm{k}_{\mathrm{l}} / \mathrm{k}_{\mathrm{T}}=\mathrm{IN}_{1}$ and $\mathrm{POC}_{\mathrm{L}}$ (labile particulate organic carbon; $\mathrm{POC}_{\mathrm{L}}=\mathrm{POC}_{\mathrm{LS}} \times \mathrm{k}_{\mathrm{l}} / \mathrm{k}_{\mathrm{T}}$ ) yield coefficient; $\mathrm{IN}_{2}=$ DOC mineralized ( $\left.\%\right) ; \mathrm{k}_{2} / \mathrm{k}_{\mathrm{T}}=\mathrm{IN}_{2}$ and DOC yield coefficient $\left(\mathrm{DOC}=\mathrm{POC}_{\mathrm{LS}} \times \mathrm{k}_{2} / \mathrm{k}_{\mathrm{T}}\right)$; $\mathrm{MC}=$ mineralized carbon $(\%)$ (inorganic compounds (on carbon basis) produced by the 3 mineralization routes); $\mathrm{t}=$ time (day); $\mathrm{k}_{1}=$ mineralization rate constant of $\mathrm{POC}_{\mathrm{L}}$ $\left(\right.$ day $\left.^{-1}\right)$ and half-life $\left(\mathrm{t}_{1 / 2}=\ln 0.5 /-\mathrm{k}_{1}\right) ; \mathrm{k}_{2}=$ leaching rate constant of POC $_{\mathrm{LS}}$ (formation of DOC) obtained from the leachate experiments $\left(\right.$ day $\left.^{-1}\right) ; \mathrm{k}_{\mathrm{T}}=\mathrm{k}_{1}+\mathrm{k}_{2}$ and half-life $\left(\mathrm{t}_{1 / 2}=\ln 0.5 /-\mathrm{k}_{\mathrm{T}}\right) ; \mathrm{k}_{3}=$ DOC mineralization rate constant $\left(\right.$ day $\left.^{-1}\right)$ and half-life $\left(\mathrm{t}_{1 / 2}=\ln 0.5 /-\mathrm{k}_{3}\right) ; \mathrm{k}_{4}=\mathrm{POC}_{\mathrm{R}}$ mineralization rate constant $\left(\right.$ day $\left.^{-1}\right)$ and half-life $\left(\mathrm{t}_{1 / 2}=\ln 0.5 /-\mathrm{k}_{4}\right)$.

In this hypothesis, the mineralization of $E$. azurea occurred through three simultaneous processes. The first one consisted of two concurrent events (parallel reactions): leaching (DOC formation) and mineralization of labile compounds $\left(\mathrm{IN}_{1}\right)$. The second route comprised the mineralization of DOC $\left(\mathrm{IN}_{2}\right)$. The third pathway includes catabolism of refractory compounds $\left(\mathrm{IN}_{3}\right)$. The POC and DOC temporal variations (recorded in the decomposition experiments) were used for determining the mineralization parameters (yield coefficients, $\mathrm{k}_{\mathrm{T}}, \mathrm{k}_{3}$ and $\mathrm{k}_{4}$ ). For fitting the kinetics we used non-linear regressions, calculated with the iterative algorithm of Levenberg-Marquardt (Press et al., 2007). A statistical analysis was performed with the remaining mass from aerobic and anaerobic decay using the $t$ test paired comparisons to detect possible significant differences between processes.

The statistical t-test was applied to the temporal variation of POC decay determined in the two conditions of dissolved oxygen availability (aerobic and anaerobic experiments). 


\subsection{Experiment of dissolved oxygen consumption}

For the experimental setup we prepared two decomposition chambers with $E$. azurea fragments (200 mg DM), with filtered ( $\phi=1.2 \mathrm{~mm}$; Millipore) water sample from the Monjolinho Reservoir (1.0 liter). Two control chambers (only aliquots of reservoir water) were also used. The chambers were aerated with clean filtered compressed air to raise the concentrations of dissolved oxygen (DO) to saturation. The chambers were closed and incubated in the dark and under controlled temperature $20.6 \pm 0.4{ }^{\circ} \mathrm{C}$ $(\mathrm{n}=84)$. Until there was evidence of stabilization, the values for oxygen consumption (65 days), $\mathrm{pH}$ (with potentiometer, Digimed DMPH-2), electric conductivity (conductivimeter, Digimed DM3) and DO concentrations (Metrohm DOmeter, Herisau AGCH-9100/E-635) were determined periodically. In each sampling day, the chambers were closed to prevent atmospheric oxygen diffusion and avoid anaerobic processes. When the DO concentration was close to $2.0 \mathrm{mg} \mathrm{L}^{-1}$, the chambers were aerated. The deoxygenation rate constant $\left(\mathrm{k}_{\mathrm{D}}\right)$ and the maximum oxygen consumption $\left(\mathrm{OC}_{\max }\right)$ were obtained by fitting the experimental results to the $1^{\text {st }}$-order kinetics model adopted in the BOD tests (Nunes et al., 2007). The fittings were performed using nonlinear regression, calculated by the iterative algorithm of Levenberg-Marquardt (Press et al., 2007).

The temporal variations of the stoichiometric relationship (amount of oxygen consumed by the amount of carbon oxidized) were calculated by the ratio between the daily rates of oxygen consumption (dOC/dt) and mineralized carbon (dMC/dt) from aerobic E. azurea decomposition.

\subsection{Experiments of gas formation}

Two anaerobic decomposition chambers were used to monitor the formation of gases using the manometric method (Cunha-Santino and Bianchini Junior, 2006). These incubations were prepared with $10.0 \mathrm{~g}$ (DM) of plant fragment per liter of reservoir water (previously filtered through $1.2 \mu \mathrm{m}$; Millipore). The chambers were kept during 213 days in the dark, under anaerobic conditions at $24.8 \pm 1.5^{\circ} \mathrm{C}(\mathrm{n}=187)$. The temperature and the volumes of gases were recorded daily, with a mercury thermometer and low pressure gauges attached to the chambers, respectively. After each measurement the decomposition chambers were depressurized. At the end of the experiment the DOM and POM fractions were fractionated and the remaining masses were determined gravimetrically, following the analytical procedures used in the decomposition experiment.

\section{Results}

The daily rates variation of DOC formation during the early stages of decomposition (6 days) of E. azurea is presented in Figure 1a. The POC and DOC kinetics owing to leaching and oxidation of labile/soluble compounds (Equations 1 and 2) of E. azurea detritus are shown in Figure 1b. According to the kinetic hypothesis, this process was accomplished on the first day, effectively contributing to the considerable mass loss $\left(113 \mathrm{mg} \mathrm{C} \mathrm{g}^{-1} \mathrm{DM}_{\text {day }}{ }^{-1}\right)$ and then driving chemical changes in the detritus (Figure 1a). From integration of the daily rates of mass loss in Figure 1b, the kinetics fittings indicated that the fast processes (dissolution and the oxidation of labile compounds) involved $27.2 \pm 2.2 \%$ of the detritus total mass $\left(\mathrm{POC}_{\mathrm{LS}}\right)$. From the kinetics fitting of the DOC temporal variation in Figure 1b, the global decay coefficient (leaching/ mineralization, $\mathrm{k}_{\mathrm{T}}$ ) was $2.07 \pm 0.63 \mathrm{day}^{-1}\left(\mathrm{t}_{1 / 2}=8 \mathrm{~h}\right.$; Table 1$)$.

Figures $1 \mathrm{c}$ and $\mathrm{d}$ show the mass loss of POC and DOC becoming slower with a decreased slope for the rise in the yield of mineralized carbon, after the $3^{\text {rd }}$ day of incubation for the two experimental conditions (anaerobic and aerobic). The yield of labile organic matter oxidation ( $\mathrm{IN}_{1}$ from Equation 1) was similar for the two incubation conditions, and involved $78.3 \%$ (under anaerobic conditions) and $80.5 \%$ of $\mathrm{POC}_{\mathrm{LS}}$ in aerobic conditions (Table 1). From the $\mathrm{POC}_{\mathrm{LS}}$ mass loss due to leaching we observed the DOC formation. On average, the maximum values for DOC fraction indicate that $5.6 \%$ of E. azurea detritus were hydrosoluble. The similarity of yields in DOC formation in (aerobic condition: $5.3 \%$ and anaerobic conditions: $5.9 \%$ ) suggests that the detritus chemical composition was the main factor that defining the loss of soluble matter (Figure 1c and d). After the increase of DOC, no decay of dissolved organic compounds were observed, the absence of mineralization resulted in null coefficients $\left(\mathrm{k}_{3}=0\right)$ for the mineralization coefficients (Table 1). The content of refractory fraction $\left(\mathrm{POC}_{\mathrm{R}}-\right.$ Equation 3) for the E. azurea detritus was $72.6 \pm 1.5 \%$. Considering the heterogeneity of detritus ( $\mathrm{POC}_{\mathrm{LS}}$ and $\mathrm{POC}_{\mathrm{R}}$ contents), no significant differences were observed during aerobic and anaerobic experiments $(\mathrm{F}=1.629, \mathrm{p}=0.8500)$, according to the kinetics fittings for the POC mass loss. The coefficient of aerobic mineralization of refractory fractions $\left(0.0029 \pm 0.0003\right.$ day $^{-1}, \mathrm{t}_{1 / 2}=0.66$ years) was 2.4 the coefficient for anaerobic mineralization $0.0012 \pm 0.0001$ day $^{-1} ; \mathrm{t}_{1 / 2}=1.53$ years (Figure $1 \mathrm{c}$ and $1 \mathrm{~d}$; Table 1). High determination coefficients $\left(\mathrm{r}^{2}\right)$ were observed from the kinetics fittings for both aerobic and anaerobic mineralization of E. azurea, according to Table 1.

The temporal variation (daily rates) of gas generation during anaerobic degradation of E. azurea showed three distinct phases in Figure 1e. The first stage lasted until the $3^{\text {rd }}$ day of incubation, with a sharp peak at the $2^{\text {nd }}$ day. This

Table 1. Model parameterization from aerobic and anaerobic decomposition of Eichhornia azurea.

\begin{tabular}{lcccc}
\hline & \multicolumn{2}{c}{ Anaerobic process } & \multicolumn{2}{c}{ Aerobic process } \\
\hline & \multicolumn{5}{c}{ Error } & Error \\
POC $_{L S}(\%)$ & 27.21 & 2.18 & 27.21 & 2.18 \\
POC $_{\mathrm{R}}(\%)$ & 72.62 & 1.50 & 72.62 & 1.50 \\
$\operatorname{POC}_{\mathrm{L}}(\%)$ & 21.30 & - & 21.93 & - \\
$\mathrm{DOC}_{(\%)} \%$ & 5.91 & 0.45 & 5.29 & 0.59 \\
$\mathrm{k}_{\mathrm{T}}\left(\right.$ day $\left.^{-1}\right)$ & 2.07 & 0.63 & 2.07 & 0.63 \\
$\mathrm{k}_{3}\left(\right.$ day $\left.^{-1}\right)$ & 0.0 & - & 0.0 & - \\
$\mathrm{k}_{4}\left(\right.$ day $\left.^{-1}\right)$ & 0.0012 & 0.0001 & 0.0029 & 0.0003 \\
$\mathrm{r}^{2}$ & 0.92 & & 0.94 & \\
\hline
\end{tabular}




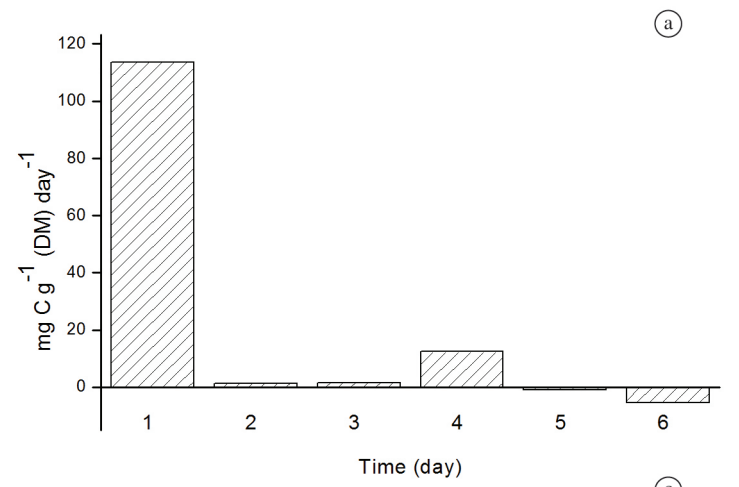

(c)
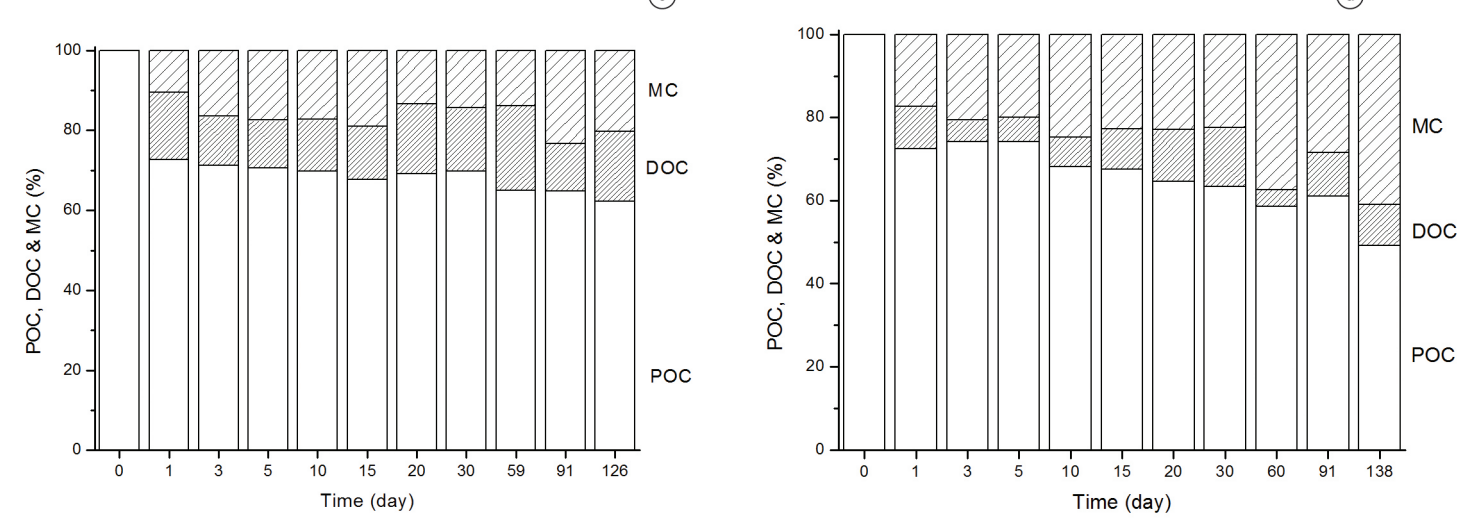

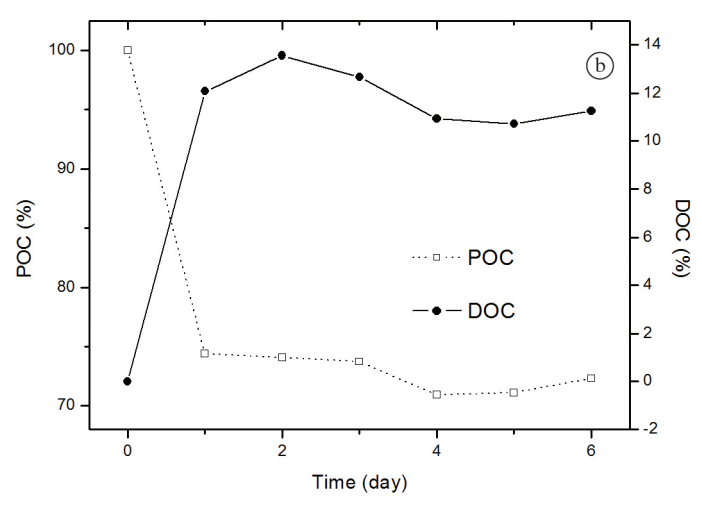

(d)

\section{OC}

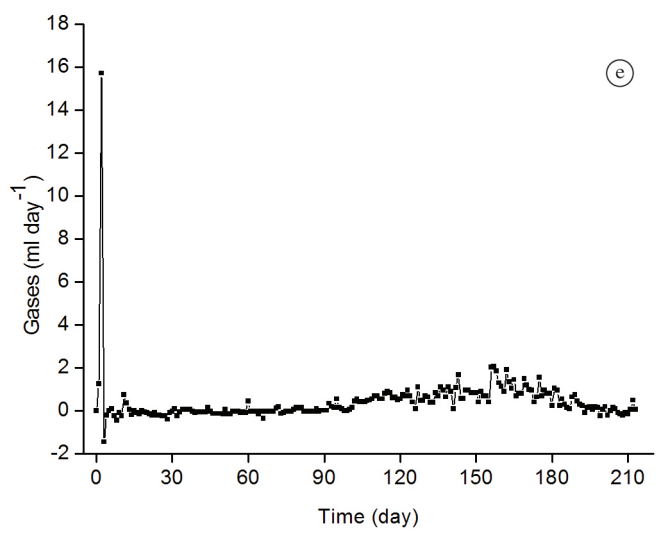

Figure 1. Eichhornia azurea decomposition. Daily rates of carbon mass loss (a), POC and DOC variations during the early stages of decomposition (b). Temporal variation of POC, DOC, and MC from anaerobic (c) e aerobic (d) decomposition and variations of the daily rates of gas formation during anaerobic decomposition (e).

indicates predominance of mineralization processes, i.e. chemical oxidation of labile compounds, which contributed to a large mass loss of detritus, more specifically in the $\mathrm{POC}_{\mathrm{LS}}$ fractions. The second stage included the $4^{\text {th }}$ to the $90^{\text {th }}$ day, being characterized by a moderate activity and small daily releases of gases. The last stage (from $91^{\text {st }}$ to $213^{\text {th }}$ day) was characterized by intense release of gases with sharp increases in daily rates (up to the $170^{\text {th }}$ day) followed by a steady decline until the $213^{\text {th }}$ day.

The fittings related to the kinetics of oxygen consumption in the mineralization of E. azurea are shown in Figure 2.
In the first stage of decomposition, the oxygen uptake was high, after which a gradual decrease occurred in the rates of oxygen uptake. The $\mathrm{OC}_{\max }$ per gram (DM) of detritus was estimated from the kinetics fitting as $165.8 \pm 2.6 \mathrm{mg}$. The deoxygenation rate constant $\left(\mathrm{k}_{\mathrm{D}}\right)$ was $0.110 \pm 0.006 \mathrm{day}^{-1}$, corresponding to a half-life $\left(\mathrm{t}_{1 / 2}\right)$ of 6.3 days. According to Equation 4, oxidation occurred in different routes (i.e. $\mathrm{IN}_{1}, \mathrm{IN}_{2}$ and $\mathrm{IN}_{3}$ ). The high oxygen consumption in the early stages of the experiment (until $20^{\text {th }}$ day) was associated with chemical and biological oxidation (i.e. respiration) involving degradation of the labile fractions 
of the detritus. The decrease in consumption from the $20^{\text {th }}$ day was attributed to the predominating oxidation of refractory fractions. The stoichiometric coefficients $(\mathrm{O} / \mathrm{C})$ under aerobic degradation of $E$. azurea were initially large, with a maximum on the $6^{\text {th }}$ day $(\mathrm{O} / \mathrm{C}=11.88)$, and then decreased continuously.

The $\mathrm{pH}$ under aerobic mineralization of E. azurea oscillated relatively little, from 6.18 to 7.30 , as shown in Figure 2. The electrical conductivity of the reservoir water (control flasks) ranged from 31.2 to $46.2 \mathrm{mS} \mathrm{cm}^{-1}$, with the largest fluctuations recorded at the beginning of decomposition. After the $42^{\text {th }}$ day the conductivity decreased monotonically (Figure 2). The electrical conductivity in the aerobic chambers with $E$. azurea detritus increased over time, reaching a maximum of $96.35 \mathrm{mS} \mathrm{cm}^{-1}$.

\section{Discussion}

The organic detritus is a mixture of substrate with different degradability degrees, in a simplistic view the detritus is assumed to belong to two major groups of substrate: easily degradable and resistant to decomposition (Berg and Laskowski, 2006). In this context, the oxidation and dissolution of protoplasmic fractions and from water soluble compounds comprise the main processes responsible for the rapid mass loss in the early stages of decomposition (Bianchini Junior and Cunha-Santino, 2011). The mass losses recorded for the detritus $\left(\mathrm{POC}_{\mathrm{LS}}\right)$ allowed evaluating the importance of fast processes in the degradation of aquatic macrophytes. The mass loss due to leaching represents ca. $20 \%$ of detritus during in situ decomposition of E. azurea, which occurred within the first 24 hours of experiment (Stripari and Henry, 2002). In contrast to the literature, the leaching process lasted four to seven days (Singhal et al., 1992; Gupta et al., 1996) during decomposition of macrophytes. Dissolved compounds released during the first step of decomposition are predominantly nonstructural substances (organic and inorganic), with high potential for use by microbial metabolism (Wetzel, 1995). The rapid loss of phosphate was observed during the first stage of E. azurea decomposition (Pagioro and Thomaz, 1999a). Basically, the differences in coefficients of mass loss (mainly in $\mathrm{k}_{3}$, Table 1) arose from the heterogeneity of detritus that defined two routes of POC mineralization: (i) involving the labile/soluble $\left(\mathrm{POC}_{\mathrm{LS}}\right)$ and (ii) that oxidized refractory fractions $\left(\mathrm{POC}_{\mathrm{R}}\right)$.

The formation of $\mathrm{POC}_{\mathrm{LS}}$ depends on the detritus properties such as origin and quality (e.g. levels of nitrogen, lignin and tannin). However, in some cases external factors (e.g. temperature; abrasion) induced changes in $\mathrm{POC}_{\mathrm{LS}}: \mathrm{POC}_{\mathrm{R}}$
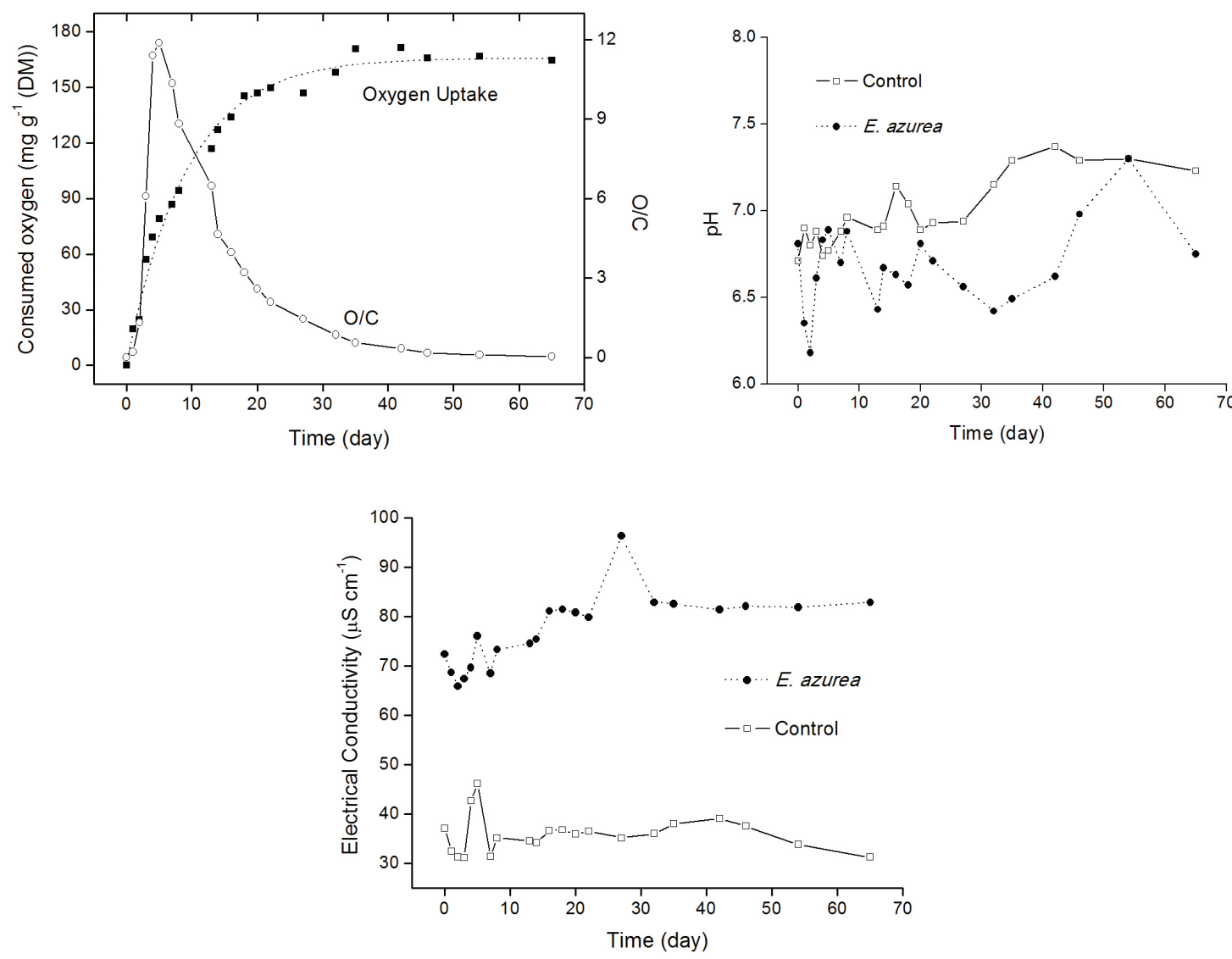

Figure 2. Temporal variation of oxygen uptake and stoichiometric coefficients from aerobic decomposition of E. azurea and its temporal variation of $\mathrm{pH}$ and electrical conductivity. 
ratio (Pacobahyba, 2002; Bitar, 2003; Fonseca, 2011). Overall, the decay coefficients for labile/soluble fractions $\left(\mathrm{k}_{1}\right)$ are higher than from refractory fraction, being also variable (e.g. from 0.02 to 6.91 day $^{-1}$; Bianchini Junior (1999)). These coefficients depend on the methodology for preparing the experiments (e.g. previous drying of the fragments, litterbag mesh size, sampling time) and on the structural characteristics of the detritus (Bärlocher, 2005). From Table 1, we infer that whatever the experimental conditions (aerobic or anaerobic media) the mass losses resulting from rapid processes (i.e. leaching) occurred at the same rate, and involved the same amount of detritus.

No mass loss for DOM (equivalent to DOC) was observed in the present study, despite that this was an expected process. The null coefficient for DOC mineralization resulted from a possible conversion of soluble compounds into humic substances with a refractory nature. Azevedo et al. (2008) observed an increased humification degree in DOM after the $60^{\text {th }}$ day of decomposition of $E$. azurea. Humic substances from anaerobic decomposition of E. azurea showed the maximum production of humic and fulvic acids on the first month of incubation (Bitar, 2003). No mass loss from leaching material was measured for decomposition of Salvinia auriculata, thus indicating the refractory nature of DOM (Cunha-Santino and Bianchini Junior, 2000). In the parameterization of the kinetics model for the aerobic DOM decomposition of leachate (i.e. DOM) from other species of aquatic macrophytes, the mineralization coefficients varied from 0.0125 day $^{-1}$ (Montrichardia arborescens) to 0.370 day $^{-1}$ (Scirpus cubensis) (Cunha and Bianchini Junior, 1998; Bianchini Junior et al., 2002).

The low values for mineralization coefficient $\left(\mathrm{k}_{4}\right)$ reflect the recalcitrant nature of the detritus, since this fraction is essentially composed by fibers that are the supporting tissues of plants consisting of lignin, hemicellulose and cellulose (Newell et al., 1995). The composition and density of the microorganism population also affected the mineralization rates of the refractory fractions (Moran and Hodson, 1989). With regard to the redox condition in the environment, the $\mathrm{POC}_{\mathrm{R}}$ mineralization coefficients $\left(\mathrm{k}_{4}\right)$ indicate distinct heterotrophic potential for the microflora, with the microorganisms involved in aerobic decomposition of lignocellulosic material being apparently adapted to the prevailing redox condition. These results are consistent with studies of cycling and degradation of organic compounds (Best et al., 1990; Moore Junior et al., 1992), in which the aerobic processes are generally faster. Decomposition of E. azurea in a reservoir during the rainy season yielded $74.8 \%$ of the detritus composed by refractory fractions $\left(\mathrm{k}_{4}\right.$ $\approx 0.0082$ day $\left.^{-1}\right)$; in an experiment during the dry season this value corresponded to $81.5 \%\left(\mathrm{k}_{4} \approx 0.0128 \mathrm{day}^{-1}\right)$ (Lima, 1999). The mass loss coefficients $\left(k_{4}\right)$ were, on average, 5.1 times those obtained in the present study. This difference was attributed mainly to the effects of environmental driving forces, e.g. photo-oxidation, turbulence, herbivory and abrasion (Allan and Castillo, 2007; Silva et al., 2011) that act directly on the detritus and were avoided in our decomposition bioassays. On the other hand, the
$\mathrm{POC}_{\mathrm{R}}$ mass loss constant rates $\left(\mathrm{k}_{4}\right)$ presented the same order of magnitude as those found in the decomposition of E. azurea in aquatic environments of the floodplain of the Parana River (Pagioro and Thomaz, 1999b). An in vitro experiment of $E$. azurea breakdown incubated with Paranapanema River water showed that the carbon mineralized in the aerobic processes were 2.17-fold faster than the anaerobic condition (Stripari and Henry, 2002). In addition, the aerobic decay of E. azurea can promote moderate depletion in the dissolved oxygen budget (CunhaSantino et al., 2010). An in situ experiment with litter bags recorded significant differences in decomposition rates for E. azurea during the flooding phase of Paraná River (Padial and Thomaz, 2006), which illustrates the importance of the water regime. In situ and in vitro decomposition experiments with $E$. azurea from Itupararanga Reservoir showed a $\mathrm{k}_{3}$ of $0.0051 \mathrm{day}^{-1}$ and $0.0025 \mathrm{day}^{-1}$, respectively, which points to differences for this process in controlled and natural conditions (Botino, 2011).

A survey on aquatic macrophytes decomposition categorized by life forms (Bianchini Junior and CunhaSantino, 2008) highlighted the heterogeneous nature of detritus, with refractory fractions being, on average, 2.8 times the labile/soluble fractions. In the present study $\mathrm{POC}_{\mathrm{R}}: \mathrm{POC}_{\mathrm{LS}}=2.4$. The survey also reported a huge range of refractory mineralization coefficients (from 0.0042 to 0.0178 day $\left.^{-1}\right)$.

Oxygen consumption has been widely used to estimate the aerobic decomposition in aquatic systems. The temporal variation of the oxygen consumption for $E$. azurea detritus in the present study was similar to recorded by Borsuk and Stow (2000) and Nunes et al. (2007). Our results were relatively close to data from aerobic degradation of $E$. azurea $\left(\mathrm{OC}_{\max }=140.0 \mathrm{mg} \mathrm{g}^{-1} \mathrm{DM}\right.$ and $\left.\mathrm{k}_{\mathrm{D}}=0.199 \mathrm{day}^{-1}\right)$ by Bitar and Bianchini Junior (2002) in the Infernão Lagoon. The $\mathrm{k}_{\mathrm{D}}$ determined in this study was lower than the average value from the aerobic decomposition of macrophytes (Cunha and Bianchini Junior, 1998; Brum et al., 1999; Farjalla et al., 1999; Bitar and Bianchini Junior, 2002). However, from the the deoxygenation coefficient, we infer that the oxygen consumption during degradation of E. azurea is a fast process.

The chemical detritus are highly heterogeneous (Gleason and Ewel, 2002), with tissues of aquatic macrophytes presenting fibers (Little, 1979; Henry-Silva et al., 2001) and soluble compounds (organic and inorganic) that are processed at different speeds. In general, detritus accumulating in sediments comprises mainly cellulose and lignin. Thus, accumulated detritus in sediments generates low pressure on dissolved oxygen availability and the hydrosoluble compounds (i.e. DOC formation) generate high oxygen uptake. These DO variations were related, in a first stage, with the oxidation of labile and chemical nature of the detritus (original organic matrix). In a second stage, they are associated with biochemical oxidations (metabolic pathways) and the types of the microorganisms responsible for heterotrophic consumption. The stoichiometric coefficients are thus related to the metabolic pathways of degradation 
by the organic compounds which are processed. Thus, all the metabolic pathways of the predominant community of microorganisms governed the stoichiometric relationships. Among the possibilities of metabolic pathways one may include: oxidative pathway via the pentose-phosphate, glycolysis (Embden-Meyerhof-Parnas) and EntnerDoudoroff (KDPG) pathways.

Depending on the amount of E. azurea detritus that enter in Monjolinho Reservoir in the detritus chain, a high oxygen uptake occurs in a short-term low intensity pressure on dissolved oxygen availability in the water column. Regarding the refractory fraction of E. azurea detritus during aerobic decomposition it will generate low intensity of oxygen demands but as a continuous and longterm process. The pressure of aerobic decay on dissolved balance of reservoir is also related with physical processes (hydraulic retention time, fetch, precipitation, atmospheric diffusion) and biological process (e.g. photosynthesis). The aerobic mineralization processes contributing to the decrease in $\mathrm{pH}$ were the oxidation processes with $\mathrm{CO}_{2}$ production and ensuing formation of bicarbonate ions and the dissolution of reduced compounds. The $\mathrm{pH}$ increases were probably related to consumption (biological assimilation) of $\mathrm{HCO}_{3}^{-}$ions. The factor responsible for small oscillations in $\mathrm{pH}$ is the formation of humic compounds, which normally buffers the medium (Cunha-Santino and Bianchini Junior, 2002). The average $\mathrm{pH}$ in the control chambers was generally higher and tended to increase throughout the experiment, probably because of a lower metabolic activity and assimilation of bicarbonates in heterotrophic processes. The protoplasmic contents of the plant tissues were the main responsible for increments of ions (e.g. carbonate and calcium oxalate) in the decomposition. The increases were related to the dominance of leaching processes (release of mineral compounds) and mineralization (e.g. $\mathrm{CO}_{2}$ formation) over the immobilization (biological assimilation) and salts formation.

Regarding the E. azurea detritus that accumulated on sediments, the low redox conditions favored the anaerobic decomposition process. In this stage frequent negative rates were observed, with predominance of gas consumption due to biological assimilation instead of gas formation. Since in this stage the redox condition is very reducing (Bitar, 2003), the driving metabolic processes were: (i) mineralization of dissolved compounds with medium potential of degradability (e.g. starches, proteins and lipids); (ii) formation of intermediate compounds of metabolic fermentation (e.g. organic acids), (iii) increase in biomass of microorganisms; (iv) denitrification and (v) anaerobic respiration of sulfate. The aanaerobic bioassays on decomposition of $E$. azurea simulating different thermal conditions $\left(18\right.$ to $27^{\circ} \mathrm{C}$ ) indicate the effect of increasing temperature on metabolism of microorganism where the maximum decomposition coefficient $\left(\mathrm{k}_{3}\right)$ was found among 25 and $27^{\circ} \mathrm{C}$ and the end products were mainly $\mathrm{CO}_{2}$ over $\mathrm{CH}_{4}$ (Bitar, 2003).
Under anaerobic conditions, the high rates of gas formation resulted from: the mineralization of organic acids and other intermediate compounds, to the formation of $\mathrm{CH}_{4}$ and to the adaptation to the heterotrophic community to environmental conditions. The decreases in the rates of gas formation were mainly attributed to: (i) high degree of refractivity in the remaining detritus with predominance of lignocellulosic compounds; (ii) formation of humic substances; (iii) change in the microbial community and (iv) restriction in the availability of nutrients and/ or intermediate products for the biological processes of assimilation.

According to the experimental procedures adopted, and the parameters from the kinetics model proposed, we concluded that: (i) with regard to the structural morphology of E. azurea, the detritus is an heterogeneous substrate (in terms of chemical composition) consisting of two fractions: a labile/ soluble $\left(\mathrm{POC}_{\mathrm{LS}}=27.21 \%\right)$ and other refractory $\left(\mathrm{POC}_{\mathrm{R}}=72.62 \%\right.$ ); (ii) The coefficient of mass loss of labile/soluble fraction was higher than the oxidation of refractory fractions (from 720 to 1670 times); (iii) In both aerobic and anaerobic conditions, the coefficients of DOC mineralization $\left(\mathrm{k}_{2}\right)$ were null, indicating the refractivity of the leached fractions; (iv) the $\mathrm{POC}_{\mathrm{R}}$ processes of mineralization $\left(\mathrm{k}_{4}\right)$ under aerobic conditions were 2.4 times faster than under anaerobic conditions; (v) Stoichiometric ratios $\mathrm{O} / \mathrm{C}$ varied with time, tending to decrease and (vi) for the anaerobic condition, gas formation was more frequent in the later stage of degradation (up the $90^{\text {th }}$ day). Overall, the results suggest that in the Monjolinho Reservoir (shallow, small and hydraulic instable environment) the E. azurea decomposition is more effective under aerobic conditions. This means that this process occurs in the water column and in the boundary zone of sediment and water column. In this aquatic environment, the leachate from the early stage of degradation of aquatic macrophytes contributes to the pool of DOC, favoring humification with humic and fulvic acid metabolism (i.e. formation and mineralization). Considering the half-life of the particulate detritus, the results indicate that in this reservoir the detritus of E. azurea will undergo an intense accumulation of autochthonous organic matter in sediments where the low redox conditions prevail, thus favoring anaerobic decay. Being decomposition a metabolic process inherent to any ecosystem, and that the breakdown of macrophytes produce as end products $\mathrm{C}$-gases, the decay of $E$. azurea will contribute do increments of $\mathrm{CO}_{2}$ on water column and atmosphere and also $\mathrm{CH}_{4}$ produced by Archaea within sediment. Within the range of temperature of this subtropical environment, biogenic C-gases emissions are more intense in the warmer months (Bitar, 2003; CunhaSantino, 2003). These degradation processes contribute intensively to the accumulation of greenhouse C-gases through the carbon dynamics.

Acknowledgments - The authors thank the Coordenadoria de Aperfeiçoamento de Pessoal de Nível Superior (CAPES) for scholarship granted. 


\section{References}

ALLAN, JD. and CASTILLO, MM., 2007. Stream ecology. Structure and function of running waters. Dordrecht: Springer. $436 \mathrm{p}$.

AZEVEDO, JCR., MIZUKAWA, A., TEIXEIRA, MC. and PAGIORO, TA., 2008. Contribuição da decomposição de macrófitas aquáticas (Eichhornia azurea) na matéria orgânica dissolvida. Oecologia Brasiliensis, vol. 12, no. 1, p. 42-56.

BÄRLOCHER, F., 2005. Leaching. In GRAÇA, MAS., BÄRLOCHER, F. and GESSNER, MO. (Eds.). Methods to study litter decomposition - a practical guide. Dordrecht: Springer. p. 33-36.

BATZER, DP. and SHARITZ, RR., 2006. Ecology of freshwater and estuarine wetlands. Berkeley: University of California Press. $568 \mathrm{p}$.

BENNER, RB., MORAN, MA. and HODSON, RE., 1986. Biogeochemical cycling of lignocellulosic carbon in marine and freshwater ecosystems: Relative contributions of prokaryotes and eukaryotes. Limnology and Oceanography, vol. 31, no. 1, p. 89100. http://dx.doi.org/10.4319/1o.1986.31.1.0089

BERG, B. and LASKOWSKI, R. 2006. Methods in studies of organic matter decay. Advances in Ecological Research, vol. 38, p. 291-331. http://dx.doi.org/10.1016/S0065-2504(05)38009-3

BEST, EPH., DASSEN, JHA., BOON, JJ. and WIEGERS, G., 1990. Studies on decomposition of Ceratophyllum demersum litter under laboratory and field conditions: losses of dry mass and nutrients, qualitative changes in inorganic compounds and consequences for ambient water and sediments. Hydrobiology, vol. 194, no. 2, p. 91-114. http://dx.doi.org/10.1007/BF00028411

BIANCHINI JUNIOR, I., 1999. Aspectos do processo de decomposição nos ecossistemas aquáticos continentais. In POMPÊO, MLM. (Ed.). Perspectivas da limnologia no Brasil. São Luís: Gráfica e Editora União. p. 21-43.

BIANCHINI JUNIOR, I. and CUNHA-SANTINO, MB., 2008. As rotas de liberação do carbono dos detritos de macrófitas aquáticas. Oecologia Brasiliensis, vol. 12, no. 1, p. 20-29. http:// dx.doi.org/10.4257/oeco.2008.1201.03

-, 2011. Model parameterization for aerobic decomposition of plant resources drowned during man-made lakes formation. Ecological Modelling, vol. 222, no. 7, p. 1263-1271. http://dx.doi. org/10.1016/j.ecolmodel.2011.01.019

BIANCHINI JUNIOR, I., PACOBAHYBA, LD. and CUNHASANTINO, MB., 2002. Aerobic and anaerobic decomposition of Montrichardia arborescens (L.) Schott. Acta Limnologica Brasiliensia, vol. 14, no. 3, p. 27-34.

BITAR, AL., 2003. Mineralização e formação de gases da degradação de Eichhornia azurea Kunth e Egeria najas Planch. São Carlos: Universidade Federal de São Carlos. 118 p. Tese de Doutorado em Ciências.

BITAR, AL. and BIANCHINI JUNIOR, I., 2002. Mineralization assays of some organic resources of aquatic systems. Brazilian Journal of Biology, vol. 62, no. 4A, p. 557-564. PMid:12659003. http://dx.doi.org/10.1590/S1519-69842002000400001

BIUDES, JFV. and CAMARGO, AFM., 2008. Estudos dos fatores limitantes à produção primária por macrófitas aquáticas no Brasil. Oecologia Brasiliensis, vol. 12, no. 1, p. 7-19.

BORSUK, ME. and STOW, CA., 2000. Bayesian parameter estimation in a mixed-order model of BOD decay. Water Research, v. 34, no. 6, p. 1830-1836. http://dx.doi.org/10.1016/S00431354(99)00346-2

BOTINO, F., 2011. Diversidade, biomassa e decomposição de macrófitas aquáticas no Reservatório Itupararanga - SP. São Carlos: Universidade de São Paulo. 120 p. Tese de doutorado em Hidráulica e Saneamento.

BRUM, PR., FARJALLA, VF., GONÇALVES JUNIOR, JF., SANTOS, AM., PÔRTO, MT., VIEIRA, EDR., FERREIRA, FM. and BIANCHINI JUNIOR, I., 1999. Aspects of uptake of dissolved oxygen in Cabiúnas and Imboassica lagoons (Macaé, RJ). Brazilian Archives of Biology and Technology, vol. 42, no. 4, p. 433-440.

CANHOTO, C. and GRAÇA, MAS., 1996. Decomposition of Eucalyptus globulus leaves and tree native leaf species (Alnus glutinosa, Castanea sativa and Quercus faginea) in a portuguese low order stream. Hydrobiologia, vol. 333, no. 2, p. 79-85. http:// dx.doi.org/10.1007/BF00017570

CLARK, DA., BROWN, S., KICKLIGHTER, DW., CHAMBERS, JQ., THOMLINSON JUNIOR, NIJ., and HOLLAND, EA., 2001. Net primary production in tropical forests: an evaluation and synthesis of existing field data. Ecological Applications, vol. 11 no. 2, p. 371-384. http://dx.doi.org/10.1890/1051-0761(2001)011[0371:NP PITF]2.0.CO;2

CORRELL, HB. and CORRELL, DS., 1972. Aquatic and wetland plants of southwestern. Stanford: Stanford University Press. 856 p.

CUNHA, MB. and BIANCHINI JUNIOR, I., 1998. Mineralização aeróbia de Cabomba piauhyensis e de Scirpus cubensis. Acta Limnologica Brasiliensia, vol. 10, no. 1, p. 81-91.

CUNHA-SANTINO, MB., 2003. Atividade enzimática, cinética e modelagem matemática da decomposição de Utricularia breviscapa da lagoa do Óleo (Estação Ecológica de Jataí, Luiz Antônio - SP). São Carlos: Universidade Federal de São Carlos. 141 p. Tese de Doutorado em Ciências.

CUNHA-SANTINO, MB. and BIANCHINI JUNIOR, I., 2000. Decomposição aeróbia e anaeróbia de Salvinia auriculata da lagoa do Infernão. In: SANTOS, JE. and PIRES, JSR. (Eds.). Estudos integrados em ecossistemas - Estação Ecológica de Jataí. São Carlos: RiMa. p. 631-643.

-, 2002. Humic substance mineralisation from a tropical oxbow lake (São Paulo, Brazil). Hydrobiologia, vol. 468, no. 1-3, p. 34-44.

-, 2006. The aerobic and anaerobic decomposition of Typha domingensis Pers. Acta Limnologica Brasiliensia, vol. 18, no. 3, p. 321-334.

CUNHA-SANTINO, MB., BIANCHINI JR, I. and OKAWA, MH., 2010. The fate of Eichhornia azurea (Sw.) Kunth. detritus within a tropical reservoir. Acta Limnologica Brasiliensia, vol. 22, no. 2, p. 109-121. http://dx.doi.org/10.1590/S2179-975X2010000200001

CURRIE, WS., YANAI, RD., PIATEK, KB., PRESCOTT, CE. and GOODALE, CL., 2003. Processes affecting carbon storage in the forest floor and in downed woody debris. In KIMBLE, JM., HEATH, LS., BIRDSEY, RA. and LAL, R. (Eds.). The potential of U.S. forest soil to sequester carbon and mitigate the greenhouse effect. Boca Raton: Lewis Publishers. p. 135-157.

FARJALLA, VF., MARINHO, CC. and ESTEVES, FA., 1999. The uptake of oxygen in the initial stages of decomposition of aquatic macrophytes and detritus from terrestrial vegetation in a tropical coastal lagoon. Acta Limnologica Brasiliensia, vol. 11, no. 2 , p. 185-193. 
FONSECA, ALS., 2011. Efeitos de variáveis fisicas e químicas na decomposição de recursos vegetais terrestres alagados em reservatórios. São Carlos: Universidade Federal de São Carlos. 137 p. Tese de Doutorado em Ciências.

FUSARI, LM., 2006. Estudo das comunidades de macroinvertebrados bentônicos das represas do rio do Monjolinho e do Fazzari no campus da UFSCar, município de São Carlos, SP. São Carlos: Universidade Federal de São Carlos. 80 p. Dissertação de Mestrado em Ecologia e Recursos Naturais.

GLEASON, SM and EWEL, KC., 2002. Organic matter dynamics on the forest floor of a Micronesian mangrove forest: an investigation of species composition shifts. Biotropica, vol. 34, no. 2, p. 190-198. http://dx.doi.org/10.1111/j.1744-7429.2002.tb00530.x

GULIS V. and SUBERKROPP K., 2003. Leaf litter decomposition and microbial activity in nutrient-enriched and unaltered reaches of a headwater stream. Freshwater Biology, vol. 48, p. 123-134. http://dx.doi.org/10.1046/j.1365-2427.2003.00985.x

GUPTA, MK., SHRIVASTAVA, P. and SINGHAL, PK., 1996. Decomposition of young water hyacinth leaves in lake water. Hydrobiologia, vol. 335, p. 33-41. http://dx.doi.org/10.1007/ BF00013680

HENRY-SILVA, GG., PEZZATO, MM., BENASSI, RF. and CAMARGO, AFM., 2001. Chemical composition of five species of aquatic macrophytes from lotic ecosystems of southern coast of the state of São Paulo (Brazil). Acta Limnologica Brasiliensia, vol.13, no. 2, p. 11-17.

JOLY, AB., 1977. Botânica: introdução à taxonomia vegetal. São Paulo: Companhia Editora Nacional. 775 p.

LIMA, N., 1999. Estudo da colonização pelos invertebrados durante o processo de decomposição de Eichhornia azurea Kunth e Eichhornia crassipes Solms na represa de Jurumirim (zona de desembocadura dos rios Paranapanema e Guareí- SP). Botucatu: Universidade Estadual Paulista Júlio de Mesquita Filho. 89 p. Dissertação de Mestrado em Ciências Biológicas (Zoologia).

LITTLE, ECS., 1979. Handbook of utilization of aquatic plants. FAO Fish. Rome: Technology Paper 187, 176 p.

LODGE, DM., 1991. Herbivory on freshwater macrophytes. Aquatic Botany, vol. 41, p. 195-224. http://dx.doi.org/10.1016/03043770(91)90044-6

MARINELLI, CE., MORETTO, EM., BRUCHA, G. and LUCCA, JV., 2000. Limnologia. In ESPÍNDOLA, ELG., SILVA, JSV., MARINELLI, CE. and ABDON, MM. (Eds.). A Bacia Hidrográfica do Rio do Monjolinho. São Carlos: RiMa. p. 133-149.

MOORE JUNIOR, PA., REDDY, KR. and GRAETZ, DA., 1992. Nutrient transformations in sediments influenced by oxygen supply. Journal of Environmental Quality, vol. 21, no. 3, p. 387393. http://dx.doi.org/10.2134/jeq1992.00472425002100030014x

MORAN, MA. and HODSON, RE., 1989. Formation and Bacterial utilization of dissolved organic carbon derived from detrital lignocellulose. Limnology and Oceanography, vol. 34, no. 6, p. 1034-1047. http://dx.doi.org/10.4319/lo.1989.34.6.1034

NEWELL, SY., MORAN, MA., WICKS, R., HODSON, RE. and ABRAHAM, TK., 1995. Productivities of microbial decomposers during early stages of decomposition of leaves of a freshwater sedge. Freshwater Biology, vol. 34, no. 1, p. 135-148. http:// dx.doi.org/10.1111/j.1365-2427.1995.tb00430.x

NOGUEIRA, MG. and MATSUMURA-TUNDISI, T., 1994. Limnologia de um sistema raso (Represa do Monjolinho - São Carlos, SP). I - Dinâmica das variáveis físicas e químicas. Revista
Brasileira de Biologia = Brazilian Journal of Biology, vol. 54, no. 1, p. 147-159.

NOTARE, M., 1992. Plantas hidrófilas e seu cultivo em aquário. Rio de Janeiro: Editora Sulamérica. 238 p.

NUNES, MF., CUNHA-SANTINO, MB. and BIANCHINI JUNIOR, I., 2007. Aerobic mineralization of carbon and nitrogen from Myriophyllum aquaticum (Vell.) Verdc. leachate. Acta Limnologica Brasiliensia, vol. 19, no. 3, p. 285-293.

PACOBAHYBA, LD., 2002. Decomposição de Staurastrum iversenii Nygaard var: americanum: efeito da qualidade do recurso, da disponibilidade de oxigênio e da temperatura. São Carlos: Universidade Federal de São Carlos. 167 p. Tese de Doutorado em Ciências.

PADIAL, AA. and THOMAZ, SM., 2006. Effects of flooding regime upon the decomposition of Eichhornia azurea (Sw.) Kunth measured on a tropical, flow-regulated floodplain (Paraná river, Brazil). River Research and Applications, vol. 22, p. 791-801. http://dx.doi.org/10.1002/rra.936

PAGIORO, TA. and THOMAZ, SM., 1999a. Influence of the decomposition of Eichhornia azurea on selected abiotic limnological variables of different environments of the floodplain of the High Paraná River. Acta Limnologica Brasiliensia, vol. 11 , no. 2, p. 157-171.

-, 1999b. Decomposition of Eichhornia azurea from limnologically different environments of the Upper Paraná River floodplain. Hydrobiologia, vol. 411, p. 45-51. http://dx.doi. org/10.1023/A:1003839704084

POTT, VJ. and POTT, A., 2000. Plantas aquáticas do Pantanal. Brasília: Embrapa. 404 p.

PRESS, WH., TEUKOLSKY, SA., VETTERLING, WT. and FLANNERY, BP., 2007. Numerical recipes: the art of scientific computing. New York: Cambridge University Press. 1256 p.

REGALI-SELEGHIM, MH., 1992. Flutuações nas comunidades planctônicas e bentônicas de um ecossistema artificial raso (Represa do Monjolinho - São Carlos - SP), com ênfase nas populações de protozoários e bactérias. São Carlos: Universidade Federal de São Carlos. 162 p. Dissertação de Mestrado em Ecologia e Recursos Naturais

SANDERMAN, J. and AMUNDSON, R., 2005. Biogeochemistry of decomposition and detrital processing. In SCHLESINGER, WH. (Ed.). Biogeochemistry. Vol. 8 Treatise on Geochemistry. Oxford: Elsevier. p. 249-316.

SANTOS, MG., CUNHA-SANTINO, MB. and BIANCHINI JUNIOR, I., 2011. Alterações espaciais e temporais de variáveis limnológicas do reservatório do Monjolinho (campus da UFSCar). Oecologia Australis, vol. 15, no. 3, p. 682-696. http://dx.doi. org/10.4257/oeco.2011.1503.18

SINGHAL, PK., GAUR, S. and TALEGAONKAR, L., 1992. Relative contribution of different decay processes to the decomposition of Eichhornia crassipes (Mart.) Solms. Aquatic Botany, vol. 42, no. 3, p. 265-272. http://dx.doi.org/10.1016/0304-3770(92)90027-G

SILVA, TSF., COSTA, MPF. and MELACK, JM., 2009. Annual net primary production of macrophytes in the eastern Amazon floodplain. Wetlands, vol. 29, no. 2, p. 747-758. http://dx.doi. org/10.1672/08-107.1

SILVA, DS., CUNHA-SANTINO, MB., MARQUES, EE. and BIANCHINI JUNIOR, I., 2011. Decomposition of aquatic macrophytes: bioassays versus in situ experiments. Hydrobiologia, 
vol. 665 , no. 1, p. 219-227. http://dx.doi.org/10.1007/s10750011-0625-4

SOTERO-SANTOS, RB., DELLAMANO-OLIVEIRA, MJ., CARVALHO, EG., MINILLO, A. and ROCHA, O., 2010. Phytoplanktonic structure and chemistry of the water in the Monjolinho Reservoir (SP, Brazil) during a cyanobacterial bloom episode. Journal of the Brazilian Society Ecotoxicology, vol. 5, no. 1, p. 63-70. http://dx.doi.org/10.5132/jbse.2010.01.011

STRIPARI, NL. and HENRY, R., 2002. The invertebrate colonization during decomposition of Eichhornia azurea Kunth in a lateral lake in the mouth zone of Paranapanema river into Jurumirim reservoir (São Paulo, Brazil). Brazilian Journal of Biology, vol. 62, no. 2, p. 293-310. PMid:12494917. http://dx.doi.org/10.1590/ S1519-69842002000200014
TARTAGLIA, D., 2001. O efeito da temperatura na degradação anaeróbia de Eichhornia azurea. São Carlos: Universidade Federal de São Carlos. 40 p. Monografia em Ciências Biológicas.

WETZEL, RG., 1995. Death, detritus and energy flow in aquatic ecosystems. Freshwater Biology, vol. 33, no. 1, p. 83-89. http:// dx.doi.org/10.1111/j.1365-2427.1995.tb00388.x

-, 2001. Limnology: lake and river ecosystems. San Diego: Academic Press. 1006 p.

WETZEL, RG. and LIKENS, GE., 1991. Limnological analyses. New York: Springer-Verlag. 391 p.

WURZBACHER, CM., BÄRLOCHER, F. and GROSSART, HP., 2010. Fungi in lake ecosystems. Aquatic Microbial Ecology, vol. 59, no. 2, p. 125-149. 